\title{
Growth and Yield of Tomato under Varied Planting Dates and Cultivars in Semi-Arid Environment
}

\author{
L. Shravika $^{1 *}$, G. Sreenivas ${ }^{2}$, A. Manohar Rao ${ }^{3}$ and A. Madhavi ${ }^{4}$ \\ ${ }^{1}$ Department of Agronomy, College of Agriculture, ${ }^{2}$ Agro Climate Research Center, ARI, \\ ${ }^{3}$ Department of Horticulture, College of Agriculture, Jayashankar Telangana State \\ Agricultural University, Rajendranagar, Hyderabad - 500 030, India \\ ${ }^{4}$ Soil Test and Crop Response, ARI, Rajendranagar, Hyderabad, India \\ *Corresponding author
}

\begin{tabular}{|l|}
\hline Ke y w o r d s \\
$\begin{array}{l}\text { Tomato, dates of } \\
\text { planting, cultivars, } \\
\text { growth, fruit yield }\end{array}$ \\
\hline Article Info \\
\hline $\begin{array}{l}\text { Accepted: } \\
\text { 11 June } 2020 \\
\text { Available Online: } \\
\text { 10 July } 2020\end{array}$ \\
\hline
\end{tabular}

A B S T R A C T

Many factors limiting tomato production in open field conditions. A field investigation was under taken to optimize the planting window and cultivar during kharif 2019 at Agriculture Research Institute, Professor Jayashankar Telangana State Agriculture University, Rajendranagar, Hyderabad to realize the higher productivity of tomato. The experiment was carried out with dates of planting (02 Jul, 12 Jul, 22 Jul, 02 Aug, 11 Aug, 23 Aug, 03 Sep and 13 Sep) as main plot treatment and cultivars US 440 \& TO-3251 (Saaho) as sub plot treatment. The study revealed that $02 \mathrm{Jul}$ planting recorded significantly higher fruit yield of 69.5 $\mathrm{t} \mathrm{ha}^{-1}$ with more plant height $(95 \mathrm{~cm})$, number of branches plant ${ }^{-1}(35.8)$, LAI (1.84) number of fruits plant ${ }^{-1}$ (41.3) and number of fruits $\mathrm{m}^{-2}(153.1)$ and this was on par with $13 \mathrm{Sep}\left(66.8 \mathrm{t} \mathrm{ha}^{-1}\right)$ and $12 \mathrm{Jul}\left(61.5 \mathrm{t} \mathrm{ha}^{-1}\right)$ plantings over rest of the dates of planting. Even though the cultivars did not differ significantly cultivar US 440 produced more fruit yield $\left(45.8 \mathrm{t} \mathrm{ha}^{-1}\right)$ over TO-3251(41.0 $\left.\mathrm{t} \mathrm{ha}^{-1}\right)$.

\section{Introduction}

Tomato (Solanum lycopersicum L.) is the second largest cultivated vegetable crop and one of the most widely consumed vegetable crop in the world after potato. Tomato can play an important role in human diet and known as protective food because of its special nutritive value and also its wide spread production. In India tomato crop occupies an area of 0.63 million ha with an annual production of 12.43 million tones and productivity of $19.60 \mathrm{t} \mathrm{ha}^{-1}$ (Cheena at al., 2018). However, the production is much less than the requirement, if balanced diet is provided to every individual.

In Telangana state tomato is first important vegetable crop that fetches great remuneration to the farmers and it is cultivated in open as well as in protected environment. In Telangana it occupies an area of 47,070 
hectares primarily under irrigated conditions with a productivity of $26.09 \mathrm{t} \mathrm{ha}^{-1}$ (Horticultural statistics at a glance, 2016).

The commercial production of tomato particularly grown under open field conditions is severely affected by various weather parameters like temperature, rainfall and humidity etc., and ultimately affect the yield and quality of fruit.

Temperature and relative humidity play a vital role in tomato growth, fruit setting, number of seeds and thereby the shape of fruits (Sharma and Tiwari, 1992). Due to high temperature physiological disorders like flower and fruit abscission are seen in tomato (Abdul-Baki, 1991).

It becomes very essential to find out the best date of transplanting to expose the plants to most conducive atmosphere for growth, fruit setting and quality characters. Favourable growing environment alone can't significantly boost up tomato productivity, also depends on the cultivars or genotype and management practices like optimum date of planting.

Increased productivity is attained only when tomato is grown with adopting improved varieties and agrotechniques. Tomato productivity at a given location depends on the potential of the genotype used and timely availability of resources (Isah et al., 2014).

Some varieties may remain favorable for many years while others might be replaced by newer cultivars after a few seasons. Hence there also need to find out the best cultivars for particular region suitable for current situation.

Keeping the above points in view the present study was conducted to evaluate the effect of dates of planting and cultivars on growth and yield of tomato.

\section{Materials and Methods}

The field experiment was conducted at Agricultural Research Institute, Rajendranagar, Hyderabad having $17^{0} 19^{\prime} \mathrm{N}$ Latitude, $78^{\circ} 23^{\prime}$ E Longitude and $542.3 \mathrm{~m}$ above mean sea level. The experiment waslaid out in split plot design with eight dates of planting (02 Jul, $12 \mathrm{Jul}, 22 \mathrm{Jul}, 02$ Aug, 11 Aug, 23 Aug, 03 Sep and 13 Sep) as main treatment and two cultivars (US 440 \& TO-3251) as sub treatments, replicated thrice. The soil of the experimental site was sandy loam in texture, neutral in reaction, low in available nitrogen, phosphorus and high in available potassium. The other package of practices used recommended for raising the crop. Data on different characters viz., growth and yield attributes and yield, were subjected to analysis of variance procedures as outlined for split plot design (Gomez and Gomez, 1984).

\section{Results and Discussion}

\section{Plant height (cm)}

Based on the analysis of variance (Table 1) dates of planting had a significant effect on all growth attributes. During the study plant height increased as the age of crop advanced. Maximum plant height was recorded in $02 \mathrm{Jul}$ planting and was on par with 03 Sep and 12 Jul, in turn 12 Jul planting was on par with 03 Sep planting plantings and were significantly superior over rest of dates of planting at all the crop growth stages. And significantly lowest plant height was recorded in 02 Aug planting. Sunil (2005) reported increased plant height with temperatures in tomato at IARI, being a heat loving crop the increase in temperature gave a near optimum condition for growth and development. The increased plant height in $02 \mathrm{Jul}, 13 \mathrm{Sep}$ and $03 \mathrm{Sep}$ plantings at all growth stages was due to relatively warmer temperature during 
vegetative phase then it may leads to hastened growth rate more than developmental rate resulting in taller plants. Plant height $(\mathrm{cm})$ was not differ significantly due to cultivars at all crop growth stages except during 50\% flowering stage. At 50\% flowering cultivar US 440 recorded significantly more plant height than TO-3251.

\section{Number of branches plant ${ }^{-1}$}

Dates of planting showed significant influence on number of branches plant ${ }^{-1}$ (Table 2) at all crop growth stages. Significantly more number of branches plant ${ }^{-1}$ was noticed in $02 \mathrm{Jul}$ planting at all crop growth stages and was on par with13 Sepand 12 Jul plantings, in turn 12 Jul planting was on par with 03 Sep planting and were significantly superior over rest of the dates of planting. And significantly lowest number of branches $^{-1}$ was recorded in 02 Aug planting.

This increase in number of branches plant ${ }^{-1}$ was due to the higher temperature that prevailed during vegetative phase resulted in greater photosynthesis and higher mobilization of assimilates (Bhuvanaswri et al., 2018). Similarly Islam et al., (2017) also reported more number of branches plant ${ }^{-1}$ with high temperatures. Number of branches plant ${ }^{-1}$ was not differ significantly due to cultivars at all crop growth stages.

\section{Leaf area index (LAI)}

Dates of planting showed significant influence on LAI at all crop growth stages (Table 3).Higher LAI was recorded in $02 \mathrm{Jul}$ planting at all crop growth stages and was on par with13 Sep and12 Jul plantings, in turn 12 Jul planting was on par with 03 Sep planting and were significantly superior over rest of the dates of planting. And significantly lowest LAI was recorded in 02 Aug planting. Increased LAI at02 Jul planting might be due to the lowest maximum temperatures prevailed during vegetative phase resulted in increased LAI due to more translocation of photosynthates (Harssema, 1977). LAI did not differ significantly with cultivars at different crop growth stages except during $50 \%$ flowering stage. During 50\% flowering cultivar US 440 recorded significantly more LAI over TO-3251(Saaho).

\section{Yield attributes}

Analysis of data revealed that all the yield attributes and yield except average fruit weight were significantly $(\mathrm{p} \leq 0.05)$ affected due to variable weather conditions (Table 3 ).

\section{Number of fruits plant ${ }^{-1}$}

Significantly more number of fruits plant $^{-1}$ (Table 4)was observed in 02 Jul planting and was on par with 13 Sep and12 Jul plantings, in turn 12 Jul planting was on par with 03 Sep planting and were significantly superior over the rest of dates of planting. And significantly lowest number of fruits plant ${ }^{-1}$ was recorded in 02 Aug planting.

The increase in number fruits plant ${ }^{-1}$ was due to negative relationship with rainfall during fruit development phase is probably due to rain enhancing fruit drop (Mutkule et al., 2018). Titilayo et al., (2014) also reported negative correlation between rainfall and number of fruits plant ${ }^{-1}$. Cultivars did not differ significantly with regarding number of fruits plant ${ }^{-1}$.

\section{Number of fruits $\mathrm{m}^{-2}$}

Significant increase in number of fruits $\mathrm{m}^{-2}$ (Table 4)was observed in 02 Jul planting and was on par with 13 Sep and12 Jul plantings, in turn 12 Jul planting was on par with $03 \mathrm{Sep}$ planting and were significantly superior over the rest of dates of planting. 
Table.1 Plant height $(\mathrm{cm})$ of tomato at various growth stages under different dates of planting and cultivars

\begin{tabular}{|c|c|c|c|c|c|}
\hline Treatments & First flower & $50 \%$ flowering & Fruit initiation & First picking & Last picking \\
\hline \multicolumn{6}{|l|}{ Date of planting } \\
\hline 02 Jul & $42^{a}$ & $59^{a}$ & $75^{a}$ & $92^{a}$ & $95^{a}$ \\
\hline $12 \mathrm{Jul}$ & $39^{\mathbf{a b}}$ & $55^{\text {ab }}$ & $71^{\text {ab }}$ & $88^{\text {ab }}$ & $91^{\mathbf{a b}}$ \\
\hline $22 \mathrm{Jul}$ & $33^{c}$ & $47^{c}$ & $58^{\mathrm{c}}$ & $77^{c}$ & $80^{c}$ \\
\hline 02 Aug & $24^{d}$ & $40^{d}$ & $43^{d}$ & $70^{d}$ & $73^{d}$ \\
\hline 11Aug & $26^{d}$ & $41^{d}$ & $47^{d}$ & $71^{d}$ & $74^{d}$ \\
\hline 23 Aug & $30^{\mathrm{c}}$ & $46^{c}$ & $55^{\mathrm{c}}$ & $76^{c}$ & $79^{c}$ \\
\hline 03 Sep & $38^{b}$ & $54^{b}$ & $68^{b}$ & $87^{b}$ & $88^{\mathbf{b}}$ \\
\hline 13 Sep & $41^{a}$ & $58^{\mathrm{a}}$ & $72^{a}$ & $90^{a}$ & $92^{a}$ \\
\hline S.Em \pm & 1 & 1 & 1 & 1 & 1 \\
\hline $\mathrm{CD}(\overline{\mathbf{P}}=0.05)$ & 3 & 4 & 4 & 4 & 4 \\
\hline \multicolumn{6}{|l|}{ Cultivar } \\
\hline US 440 & 34 & 51 & 62 & 82 & 84 \\
\hline TO-3251 & 34 & 49 & 60 & 81 & 84 \\
\hline S.Em \pm & 0.5 & 0.5 & 0.5 & 0.7 & 0.4 \\
\hline $\mathrm{CD}(\overline{\mathrm{P}}=\mathbf{0 . 0 5})$ & NS & 1.5 & NS & NS & NS \\
\hline \multicolumn{6}{|c|}{ Interaction (D X V) } \\
\hline \multicolumn{6}{|c|}{ Factor(V)at same level of $D$} \\
\hline S. Em \pm & 2 & 2 & 2 & 2 & 2 \\
\hline $\mathrm{CD}(\overline{\mathrm{P}=0.05})$ & NS & NS & NS & NS & NS \\
\hline \multicolumn{6}{|c|}{ Factor (D)at same level of $\mathbf{V}$} \\
\hline S. Em \pm & 1 & 2 & 2 & 2 & 1 \\
\hline $\mathrm{CD}(\mathbf{P = 0 . 0 5})$ & NS & NS & NS & NS & NS \\
\hline
\end{tabular}

Table.2 Number of branches plant ${ }^{-1}$ of tomato at various growth stages under different dates of planting and cultivars

\begin{tabular}{|c|c|c|c|c|c|}
\hline Treatments & First flower & $50 \%$ flowering & Fruit initiation & First picking & Last picking \\
\hline \multicolumn{6}{|c|}{ Date of planting } \\
\hline 02 Jul & $13.1^{\mathrm{a}}$ & $16.8^{\mathrm{a}}$ & $20.5^{\mathrm{a}}$ & $36.9^{\mathrm{a}}$ & $35.8^{\mathrm{a}}$ \\
\hline 12 Jul & $12.3^{\mathbf{a b}}$ & $15.3^{\mathbf{a b}}$ & $18.4^{\mathrm{ab}}$ & $32.9^{\text {ab }}$ & $31.9^{\mathbf{a b}}$ \\
\hline 22 Jul & $9.8^{\mathbf{c}}$ & $11.4^{\mathrm{c}}$ & $12.8^{\mathrm{c}}$ & $26.8^{\mathrm{c}}$ & $25.8^{\mathrm{c}}$ \\
\hline 02 Aug & $8.2^{d}$ & $9.0^{d}$ & $8.9^{\mathrm{d}}$ & $19.8^{d}$ & $19.8^{d}$ \\
\hline 11Aug & $8.4^{\mathrm{d}}$ & $9.3^{d}$ & $9.2^{d}$ & $20.0^{d}$ & $20.0^{d}$ \\
\hline 23 Aug & $9.6^{\mathrm{c}}$ & $10.9^{\mathrm{c}}$ & $12.1^{\mathrm{c}}$ & $25.8^{\mathrm{c}}$ & $25.1^{\mathrm{c}}$ \\
\hline 03 Sep & $11.2^{b}$ & $13.7^{b}$ & $16.4^{\mathrm{b}}$ & $31.9^{b}$ & $30.7^{\mathbf{b}}$ \\
\hline 13 Sep & $12.7^{\mathrm{a}}$ & $15.5^{\mathrm{a}}$ & $18.9^{\mathrm{a}}$ & $34.2^{\mathrm{a}}$ & $33.2^{\mathrm{a}}$ \\
\hline S.Em \pm & 0.3 & 0.6 & 0.8 & 1.6 & 1.5 \\
\hline CD $(\mathbf{P}=0.05)$ & 1.1 & 1.9 & 2.6 & 4.9 & 4.5 \\
\hline \multicolumn{6}{|l|}{ Cultivars } \\
\hline US 440 & 10.7 & 13.2 & 14.8 & 28.9 & 28.1 \\
\hline TO-3251 & 10.6 & 12.3 & 14.2 & 28.2 & 27.5 \\
\hline S.Em+ & 0.1 & 0.3 & 0.4 & 0.5 & 0.5 \\
\hline $\mathrm{CD}(\overline{\mathbf{P}}=\mathbf{0 . 0 5})$ & NS & NS & NS & NS & NS \\
\hline \multicolumn{6}{|c|}{ Interaction (D X V) } \\
\hline \multicolumn{6}{|c|}{ Factor $(V)$ at same level of $D$} \\
\hline S. Em \pm & 0.5 & 0.9 & 1.2 & 2.3 & 2.1 \\
\hline CD $(\mathbf{P}=0.05)$ & NS & NS & NS & NS & NS \\
\hline \multicolumn{6}{|c|}{ Factor (D) at same level of $\mathrm{V}$} \\
\hline S. Em \pm & 0.4 & 0.9 & 1.1 & 1.9 & 1.8 \\
\hline CD $(P=0.05)$ & NS & NS & NS & NS & NS \\
\hline
\end{tabular}


Table.3 Leaf area index (LAI) of tomato at various growth stages under different dates of planting and cultivars

\begin{tabular}{|c|c|c|c|c|c|}
\hline Treatments & First Flower & $50 \%$ flowering & Fruit initiation & First picking & Last picking \\
\hline \multicolumn{6}{|l|}{ Date of planting } \\
\hline 02 Jul & $0.16^{\mathrm{a}}$ & $0.24^{\mathrm{a}}$ & $0.92^{\mathrm{a}}$ & $1.84^{\mathrm{a}}$ & $0.66^{\mathrm{a}}$ \\
\hline $12 \mathrm{Jul}$ & $0.14^{\text {ab }}$ & $0.21^{\text {ab }}$ & $0.82^{\text {ab }}$ & $1.64^{\mathrm{ab}}$ & $0.60^{\mathrm{ab}}$ \\
\hline 22 Jul & $0.08^{\mathbf{c}}$ & $0.13^{\mathrm{c}}$ & $0.53^{\mathrm{c}}$ & $1.05^{\mathrm{c}}$ & $0.41^{\mathrm{c}}$ \\
\hline 02 Aug & $0.02^{d}$ & $0.07^{d}$ & $0.23^{d}$ & $0.52^{d}$ & $0.14^{d}$ \\
\hline 11Aug & $0.03^{d}$ & $0.08^{d}$ & $0.24^{d}$ & $0.53^{d}$ & $0.20^{d}$ \\
\hline 23 Aug & $0.07^{\mathbf{c}}$ & $0.12^{\mathrm{c}}$ & $0.45^{\mathrm{c}}$ & $0.90^{\mathrm{c}}$ & $0.36^{\mathbf{c}}$ \\
\hline 03 Sep & $0.12^{b}$ & $0.18^{b}$ & $0.73^{b}$ & $1.45^{b}$ & $0.53^{b}$ \\
\hline 13 Sep & $0.15^{\mathrm{a}}$ & $0.22^{a}$ & $0.86^{\mathrm{a}}$ & $1.72^{\mathrm{a}}$ & $0.64^{\mathrm{a}}$ \\
\hline S.Em \pm & 0.01 & 0.01 & 0.06 & 0.12 & 0.03 \\
\hline $\mathrm{CD}(\mathrm{P}=0.05)$ & 0.03 & 0.03 & 0.18 & 0.36 & 0.11 \\
\hline \multicolumn{6}{|l|}{ Cultivars } \\
\hline US 440 & 0.10 & 0.17 & 0.62 & 1.25 & 0.46 \\
\hline TO-3251 & 0.09 & 0.15 & 0.57 & 1.16 & 0.43 \\
\hline S.Em \pm & 0.003 & 0.004 & 0.03 & 0.05 & 0.01 \\
\hline $\mathrm{CD}(\overline{\mathrm{P}}=0.05)$ & NS & 0.01 & NS & NS & NS \\
\hline \multicolumn{6}{|c|}{ Interaction (D X V) } \\
\hline \multicolumn{6}{|c|}{ Factor (V)at same level of D } \\
\hline S. Em \pm & 0.01 & 0.01 & 0.08 & 0.17 & 0.05 \\
\hline $\mathrm{CD}(\mathrm{P}=0.05)$ & NS & NS & NS & NS & NS \\
\hline \multicolumn{6}{|c|}{ Factor (D)at same level of $\mathbf{V}$} \\
\hline S. Em \pm & 0.01 & 0.01 & 0.08 & 0.15 & 0.04 \\
\hline $\mathrm{CD}(\mathrm{P}=0.05)$ & NS & NS & NS & NS & NS \\
\hline
\end{tabular}

Table.4 Yield and yield attributing characters of tomato under different dates of Planting and cultivars

\begin{tabular}{|c|c|c|c|c|}
\hline Treatments & Number of fruits plant ${ }^{-1}$ & Number of fruits $\mathbf{m}^{-2}$ & Average fruit weight (g) & $\begin{array}{c}\text { Fruit yield } \\
\left(t \text { ha }^{-1}\right)\end{array}$ \\
\hline \multicolumn{5}{|l|}{ Date of planting } \\
\hline $02 \mathrm{Jul}$ & $41.3^{\mathrm{a}}$ & $153.1^{\mathrm{a}}$ & 48.6 & $69.5^{a}$ \\
\hline $12 \mathrm{Jul}$ & $38.0^{\text {ab }}$ & $140.9^{\text {ab }}$ & 45.0 & $61.5^{\text {ab }}$ \\
\hline $22 \mathrm{Jul}$ & $24.8^{\mathrm{c}}$ & $91.7^{\mathbf{c}}$ & 39.7 & $34.2^{\mathrm{c}}$ \\
\hline 02 Aug & $10.6^{d}$ & $39.2^{d}$ & 33.4 & $12.3^{d}$ \\
\hline 11Aug & $14.6^{d}$ & $54.1^{d}$ & 37.1 & $16.8^{d}$ \\
\hline 23 Aug & $23.6^{\mathbf{c}}$ & $87.5^{\mathrm{c}}$ & 39.6 & $32.3^{\mathrm{c}}$ \\
\hline 03 Sep & $33.1^{b}$ & $122.4^{b}$ & 44.0 & $53.5^{b}$ \\
\hline 13 Sep & $40.2^{a}$ & $148.8^{a}$ & 45.7 & $66.8^{a}$ \\
\hline S.Em \pm & 2.5 & 9.3 & 4.4 & 3.9 \\
\hline $\mathrm{CD}(\overline{\mathbf{P}}=0.05)$ & 7.7 & 28.4 & NS & 11.8 \\
\hline \multicolumn{5}{|l|}{ Cultivars } \\
\hline US 440 & 28.7 & 106.3 & 43.3 & 45.8 \\
\hline TO-3251 & 27.8 & 103.1 & 40.0 & 41.0 \\
\hline S.Em \pm & 0.7 & 2.6 & 1.7 & 2.2 \\
\hline $\mathrm{CD}(\overline{\mathbf{P}}=0.05)$ & NS & NS & NS & NS \\
\hline \multicolumn{5}{|l|}{ Interaction (D X V) } \\
\hline \multicolumn{5}{|c|}{ Factor(V) at same level of D } \\
\hline S. Em \pm & 3.5 & 13.1 & 6.2 & 5.4 \\
\hline $\mathrm{CD}(\overline{\mathrm{P}=0.05)}$ & NS & NS & NS & NS \\
\hline \multicolumn{5}{|c|}{ Factor (D)at same level of $\mathbf{V}$} \\
\hline S. Em \pm & 2.9 & 10.7 & 5.5 & 5.9 \\
\hline $\mathrm{CD}(\overline{\mathrm{P}=0.05})$ & NS & NS & NS & NS \\
\hline
\end{tabular}


And significantly lowest number of fruits $\mathrm{m}^{-2}$ was recorded in 02 Aug planting. The increase in number of fruits $\mathrm{m}^{-2}$ was due to increased number of fruits plant $^{-1}$ at respective dates of planting.Cultivars did not differ significantly with regarding number of fruits $\mathrm{m}^{-2}$.

\section{Average fruit weight (g)}

Dates of planting and cultivars did not show any significant influence on average fruit weight ( $\mathrm{g}$ ) of tomato (Table 4).

\section{Fruit yield (t ha $\left.{ }^{-1}\right)$}

Significantly more fruit yield $\mathrm{t} \mathrm{ha}^{-1}$ (Table 4) was observed in $02 \mathrm{Jul}$ planting and was on par with 13 Sep and12 Jul plantings, in turn 12 Jul planting was on par with 03 Sep planting and were significantly superior over the rest of dates of planting.

And significantly lowest fruit yield was recorded in 02 Aug planting. The increased fruit yield from the current experiment was due to positively correlated growth and yield attributes with fruit yield of tomato. This result confirmed the earlier findings of Srivastava et al., (2013) and Mohanthy (2003).Cultivars did not differ significantly with regarding fruit yield of tomato.

Based on the experiment result optimum planting time for tomato would be from $02 \mathrm{Jul}$ (69.5 $\left.\mathrm{t} \mathrm{ha}^{-1}\right)$ to $12 \mathrm{Jul}\left(61.5 \mathrm{t} \mathrm{ha}^{-1}\right)$ and on 13 Sep $\left(66.8 \mathrm{t} \mathrm{ha}^{-1}\right)$ proved to be best to obtain higher fruit yield in Semi Arid environment.

\section{References}

Abdul-Baki, A. A. 1991. Tolerance of tomato cultivars and selected germplasm to heat stress. J. Am. Soc. Hortic. Sci. 116(6): 1113-1116.

Bhuvanaswri, P., Geethalakshmi, V.,
Ragavan, T., Krishnamoorthy, V and Sivakumar, T. 2018. Upshot of Various Transplanting Date and Nitrogen Doses on Growth and Yield of Tomato over Trichy Region of Tamil Nadu. Int.J.Curr.Microbiol.App.Sci.7(3): 1565-1569.

Cheena, J., Saidaiah, P., Geetha, A and Tejaswini, N. 2018. Effect of sowing dates on yield and growth of indeterminate tomato varieties under poly house conditions. J. Pharmacogn. Phytochem. 7(2): 880-882.

Gomez, K.A and Gomez, A.A. 1984. Statistical Procedures for Agricultural Research ( ${ }^{\text {st }}$ Edition), Jhon Wiley and Sons, Wiley and Sons, Wiley Inter Science Publication, New York, USA., 680.

Harssema, H. 1977. Root temperature and growth of young tomato plants.Ph.D thesis. Wageningen.

Horticultural statistics at a glance 2016, Horticulture Statistics Division.

Isah, A.S., Amans, E.B., Odion, E.C and Yusuf, A.A. 2014. Growth Rate and Yield of Two Tomato Varieties (Lycopersicon esculentum Mill) under Green Manure and NPK Fertilizer Rate Samaru Northern Guinea Savanna. Int. J. Agron. 1-8.

Islam, Mohammad Mahbub Islam, Md. Abubakar Siddi1, Nigar Afsana, Mominul Haque Rabin, Md. Delwar Hossain, Suraya Parvin. 2017. Variation in Growth and Yield of Tomato at Different Transplanting Time. Int. J. Sci. Res. Pub. 7(2): 142-145.

Mohanthy, B.K. 2003. Genetic viability correlation and path coefficient studies in tomato. I. J. Agri. Res.37(1): 68-71.

Mutkule, D.A., Jadhav, R.A and Khobragade, A.M. 2018. Influence of different thermal regimes and phenophases on fruit yield of tomato varieties. $J$. Pharmacog. Phytochem.1: 3029-3031. 
Sharma, N. K and Tiwari, R.S. 1992. Effects of dates of planting on growth and yield of Tomato (Lycopersicon esculentum Mill.) cv. "Pusa Ruby". Prog. Hort. 24 (34): 188-191.

Srivastava, K., Kumari, K., Singh, S. P and Kumar R. 2013. Association studies for yield and its component traits in tomato (Solanum lycopersicum L.). Plant Arch. 13 (1): 105-112.

Sunil, K.M. 2005.Characterizing Thermal
Environment and Spectral Reflectance in Relation to Growth and Yield of Tomato and Bottle Gourd. Ph. D. Thesis. Indian Agricultural Research Institute, New Delhi.

Titilayo, O., Oladitan Folorunso, $\mathrm{M}$ and Akinseye. 2014. Influence of Weather Elements on Phenological Stages and Yield Components of Tomato Varieties in Rainforest Ecological Zone, Nigeria. J. Nat. Sci. Res. 4(12): 19-23.

\section{How to cite this article:}

Shravika. L., G. Sreenivas, A. Manohar Rao and Madhavi. A. 2020 Growth and Yield of Tomato under Varied Planting Dates and Cultivars in Semi-Arid Environment. Int.J.Curr.Microbiol.App.Sci. 9(07): 967-973. doi: https://doi.org/10.20546/ijcmas.2020.907.113 